\title{
Pendidikan Formal Anak Pada Keluarga Petani Ikan Di Desa Pudak Kecamatan Kumpeh Ulu Kabupaten Muaro Jambi Provinsi Jambi
}

\author{
${ }^{1}$ Asmaida dan ${ }^{2}$ Arosidin \\ ${ }^{1}$ Program Studi Agribisnis, Fakultas Pertanian Universitas Batanghari \\ ${ }^{2}$ Alumni Program Studi Agribisnis Fakultas Pertanian Universitas Batanghari \\ J1. Slamet Riyadi-Broni, Jambi. 36122. Telp. +6274160103 \\ 1email korespondensi : asmaida.syandri@yahoo.co.id
}

\begin{abstract}
The study aimed to describe the level children's formal education in fisherman families, and the perception of the families toward to the formal education of their children, as well as analyze the factors that effect the level of formal education of their children in Pudak Village, Kumpeh Ulu District, Muaro Jambi Province. Data analysis used descriptive methods both qualitatively and quantitatively and multiple linear regression analysis. The results showed that the distribution of the level of formal education of fish farmers' children was uneven, the percentage in the lower education category (elementary and junior high) amounted to $48.40 \%$, the moderate education category (SLTA) by $38.71 \%$ and the higher education category (D3 and S1) by $12.89 \%$. Farmers evaluate that formal education is important for children, to meet think broadly as a childrent provision in the future so that they have a better live than their parents. There are two factors among the six factors (age of the head of the family, the education of the head of the family, the number of dependents of the head of the family, the income of the head of the family, the distance of the educational facilities, the sex of the child) showed significantly affect the level of formal education of the child in the fish farming family, namely family income and the distance between their residence and the educational facilities. The coefficient of determination of $85.5 \%$ which means that both were able to explain the child's formal education level as an independent variable and $14.5 \%$ cannot be explained by the model but was explained by other factors outside of the model.
\end{abstract}

Keywords: Formal Education, Children, Fish Farmers

\begin{abstract}
Abstrak. Penelitian bertujuan untuk mendeskripsikan sebaran tingkat pendidikan formal anak pada keluarga petani ikan, dan persepsi keluarga petani ikan terhadap pendidikan formal anak, serta menganalisis faktor-faktor yang mempengaruhi tingkat pendidikan formal anak petani ikan di Desa Pudak Kecamatan Kumpeh Ulu Kabupaten Muaro Jambi Provinsi Jambi. Analisis data menggunakan metode deskriptif baik secara kualitatif maupun kuantitatif dan analisis regresi linier berganda. Hasil penelitian menunjukan bahwa sebaran tingkat pendidikan formal anak petani ikan di Desa Pudak Kecamatan Kumpeh Ulu tidak merata, persentase pada kategori pendidikan rendah (SD dan SMP) sebesar 48,40\%, kategori pendidikan sedang (SLTA) sebesar $38,71 \%$ dan kategori pendidikan tinggi (D3 dan S1) sebesar 12,89\%. Petani mempersepsikan bahwa pendidikan formal merupakan hal yang penting untuk anak, melalui pendidikan dapat memperluas pemikiran dan pengetahuan sebagai bekal hidup anak di masa yang akan datang sehingga si anak mempunyai pekerjaan yang layak dan kehidupannya lebih baik dari kondisi orang tuanya. Dari enam faktor (umur kepala keluarga, pendidikan kepala keluarga, jumlah tanggungan kepala keluarga, penghasilan kepala keluarga, jarak sarana pendidikan, jenis kelamin anak) yang dimasukan dalam model, ada dua faktor yang mempengaruhi tingkat pendidikan formal anak pada keluarga petani ikan yaitu penghasilan keluarga dan jarak tempat tinggal dengan sarana pendidikan. Koefisien determinasi sebesar 85,5\% yang berarti bahwa kedua faktor tersebut sebagai variabel bebas mampu menjelaskan tingkat pendidikan formal anak sebagai variabel tidak bebas dan $14,5 \%$ tidak dapat dijelaskan oleh model tetapi dijelaskan oleh faktor lain di luar model tersebut.
\end{abstract}

Kata kunci: Pendidikan Formal, Anak, Petani Ikan

\section{PENDAHULUAN}

Pendidikan merupakan kebutuhan utama yang harus dimiliki oleh setiap manusia, karena pendidikan merupakan salah satu sarana dalam meningkatkan taraf hidup manusia. Pendidikan secara umum mempunyai arti suatu proses kehidupan dalam mengembangkan diri tiap individu untuk dapat hidup dan melangsungkan kehidupan. Sehingga menjadi seorang yang terdidik itu sangat penting. Tanpa pendidikan sama sekali mustahil suatu kelompok manusia (dalam hal ini keluarga petani) dapat hidup berkembang sejalan aspirasi (cita-cita) untuk maju, sejahtera dan bahagia. Pendidikan sebagai salah satu kebutuhan hidup, salah satu fungsi sosial, sebagai bimbingan, dan sebagai sarana pertumbuhan yang mempersiapkan diri membentuk disiplin hidup. Hasbullah (2012), menyatakan bahwa pendidikan adalah tanggung jawab bersama antara keluarga, masyarakat, dan pemerintah. Sekolah hanyanlah pembantu kelanjutan pendidikan dalam keluarga sebab pendidikan yang pertama dan utama diperoleh anak adalah dalam keluarga". Maka dari itu orangtua memiliki tanggung jawab untuk mendidik, mengasuh dan membimbing anak- anaknya untuk mencapai tahapan tertentu yang menghantarkan anak untuk memperoleh masa depan yang lebih baik.

Keberadaan petani ikan Indonesia pada masa sekarang, masih tergolong petani tradisional yang memiliki produktivitas rendah. Faktor penyebab utama rendahnya produktivitas adalah rendahnya kualitas SDM yang mengelola sektor perikanan. Rendahnya SDM dapat menyebabkan rendahnya pendapatan dan pendapatan yang 
rendah dapat berakibat semakin meningkatnya kemiskinan petani ikan. Persoalan kemiskinan inilah yang menjadi penyebab ketidakmampuan petani ikan untuk meningkatkan kualitasnya, sehingga inovasi dan transfer pengetahuan tidak terjadi (Dahuri 2004). Hal itu dapat menunjukan bahwa untuk menghasilkan SDM yang berkualitas, keluarga harus memaksimalkan fungsinya sebagai lembaga pendidikan. Selain itu, peran keluarga terutama orang tua sangat penting dalam proses pendidikan anak.

Terciptanya generasi yang baik merupakan keberhasilan dari pendidikan yang formal diberikan kepada anak didik dan tidak terlepas dari pengaruh - pengaruh dari setiap faktor pendidikan seperti dilingkungan masyarakat, sekolah, dan lainnya. Pada pendidikan formal maka tingkat pendidikan anak juga diperhatikan untuk menunjang dan membuat si anak tersebut menjadi pribadi yang berahklak, maka dari itu perlu pertimbangan untuk memberikan pendidikan formal mulai dari tingkat dasar sampai perguruan tinggi sangatlah penting untuk di perhatikan bagi si anak. Hal ini juga tergantung bagaimana persepsi, pandangan, pendapat orang tua terhadap pendidikan formal untuk sianak tersebut.

Diharapkan setelah mengetahui tentang persepsi petani ikan terhadap pendidikan formal sianak, dapat menumbuhkan minat dan merubah pola pikirnya menjadi semakin berwawasan yang baik dan juga orang tua yang akan memberikan pendidikan formal anaknya mulai dari pendidikan dasar sampai keperguruan tinggi sehingga dapat mengetahui secara luas betapa pentingya pendidikan formal dengan melanjutkan ke jenjang perguruan tinggi.

Orang tua yang menerapkan pendidikan pada keluarganya ada yang sangat ketat, longgar dan fleksibel atau luwes ternyata mempunyai dampak yang berbeda-beda bagi pembentukan pribadi anak itu sendiri. Dalam kehidupan sehari-hari orang tua ada yang mengharapkan agar anak-anaknya mengikuti jejak dirinya, ada yang membiarkan secara bebas dan ada pula yang bersikap masa bodoh. Pandangan orang tua terhadap pendidikan formal anak berbeda-beda, ada yang positif dan ada yang negatif sehingga memberikan dampak langsung terhadap kehidupan sosial anak. Anak dapat beradaptasi dengan lingkungan pergaulan pada masyarakat sekitar, juga sangat bergantung pada pola pendidikan yang diberikan orang tua atau keluarga kepada anak itu sendiri.

Di Desa Pudak Kecamatan Kumpeh Ulu Kabupaten Muaro Jambi, Pendidikan masih tergolong rendah, hal ini karena kebiasaan dan kesadaran dari orang tua dan anak yang masih kurang tentang pentingnya pendidikan. Karena kebiasaan tersebut anak lebih memilih bekerja dari pada melanjutkan sekolahnya, Ketika anak usia sekolah seharusnya bersekolah, mereka lebih ingin memilih bekerja mengikuti jejak orang tuanya yang bekerja sebagai petani ikan. Karena anak melihat dari segi ekonomi orang tuanya hidup sejahtera sehingga anak menganggap bahwa pendidikan tidaklah terlalu penting dan juga kurangnya dorongan orang tua untuk memberikan pendidikan terhadap anak juga masih rendah sehingga anak lebih memilih untuk bekerja dari pada bersekolah.

Bertitik tolak dari uraian di atas maka penulis tertarik untuk melakukan penelitian tentang Pendidikan Formal Anak Pada Keluarga Petani Ikan Di Desa Pudak Kecamatan Kumpeh Ulu Kabupaten Muaro Jambi Provinsi Jambi, dengan tujuan mendeskripsikan sebaran tingkat pendidikan formal anak pada keluarga petani ikan dan persepsi keluarga petani ikan terhadap pendidikan formal anak serta menganalisis faktor-faktor yang mempengaruhi tingkat pendidikan formal anak pada keluarga petani ikan di Desa Pudak Kecamatan Kumpeh Ulu Kabupaten Muaro Jambi Provinsi Jambi.

\section{METODE PENELITIAN}

Metode penelitian yang digunakan adalah metode survei. Menurut Silalahi, U. 2010, bahwa survei adalah suatu usaha untuk mendapatkan dan mengumpulan data dan informasi dari berbagai sumber. Berdasarkan sumber data terdiri dari data primer dan data sekunder. Untuk data primer, pengumpulan data dilakukan dengan cara menggunakan daftar kuesioner dan wawancara langsung dengan responden tentang sebaran pendidikan formal anak, persepsi kepala keluarga petani ikan terhadap pendidikan dan faktor-faktor yang mempengaruhinya dan observasi dilapangan, sedangkan untuk data sekunder pengumpulan data dilakukan dengan studi pustaka menyangkut profil desa tempat dilakukannya penelitian yang diperoleh dari Kantor Kepala Desa Pudak, Kantor BPS Provinsi Jambi dan juga dari sumber-sumber lain yang dapat dipertanggungjawabkan. Berdasarkan jenis data yang digunakan berdasarka waktunya adalah menggunakan jenis data cross section dengan skala ukur jenis data rasio dan nominal.

Pengambilan sampel menggunakan metode purposive sampling, yaitu pelaksanaannya dilaksanakan dengan cara sengaja (Singarimbun, 1982). Populasi yang diteliti adalah keluarga petani ikan yang memiliki anak usia Sekolah Dasar hingga Perguruan Tinggi (umur anak 7-24 tahun) yang diwakili oleh Kepala Keluarga sebagai responden. Winarno (1994), menyatakan untuk pedoman umum saja dapat dikatakan bahwa bila populasi cukup homogen, terhadap populasi dibawah 100 dapat digunakan sampel sebesar 50\% dan bila populasi diatas 100 diambil sampel sebesar $15 \%$ dan juga sampel hendaknya diatas 30 orang besarnya. Berdasarkan pertimbangan di atas maka sampel yang diambil adalah 31 Kepala Keluarga atau sebesar 16\% dari total (190) petani ikan yang ada di Desa Pudak Kecamatan Kumpeh Ulu Kabupaten Muaro Jambi Provinsi Jambi.

Untuk mendeskripsikan sebaran tingkat pendidikan formal anak petani ikan dan persepsi petani ikan yang diwakili oleh kepala keluarga terhadap pendidikan formal anak menggunakan analisis deskriptif. Menurut (Sugiono, 2009) 
analisis deskriptif adalah suatu metode yang berfungsi untuk mendeskripsikan atau memberi gambaran terhadap objek yang diteliti melalui data atau sampel yang telah terkumpul sebagaimana adanya tanpa melakukan analisis dan membuat kesimpulan yang berlaku untuk umum. Untuk mengetahui faktor-faktor yang berpengaruh terhadap tingkat pendidikan anak dalam keluarga menggunakan rumus :

$Y=a+b_{1} X_{1}+b_{2} X_{2}+b_{3} X_{3}+b_{4} X_{4}+b_{5} X_{5}+b_{6} D_{6}+b_{7} D_{7}+e$

Dimana :

$\mathrm{Y}=$ Pendidikan formal anak petani ikan (tahun)

$\mathrm{X}_{1}=$ Umur kepala keluarga (Tahun)

$\mathrm{X}_{2}=$ Tingkat pendidikan kepala keluarga (tahun)

$\mathrm{X}_{3}=$ Jumlah tanggungan kepala keluarga (orang)

$\mathrm{X}_{4}=$ Penghasilan kepala keluarga (Rp/bulan)

$\mathrm{X}_{5}=$ Jarak dengan sarana pendidikan $(\mathrm{km})$.

D6 $=$ Jenis kelamin; $1=$ untuk laki-Iaki dan $0=$ untuk perempuan

D7 $=$ Status kepemilikan lahan; $1=$ Petani ikan pemilik dan $0=$ Petani ikan penggarap

$\mathrm{a}=$ Konstanta

$\mathrm{b}=$ Koefisien regresi

e $=$ Faktor kesalahan/Error

Selanjutnya untuk menguji seberapa besar variasi tidak bebas dapat di jelaskan oleh variabel bebas dengan rumus R2 sebagai berikut:

$\mathrm{R}^{2}=\frac{\Sigma y i x i}{\Sigma y i}$

Keterangan :

$\mathrm{R}^{2}=$ Koefisien Determinasi

$\mathrm{b}_{1}=$ Parameter Variabel Bebas

$\mathrm{y}_{\mathrm{i}}=$ Variabel Terikat

$\mathrm{Xi}=$ Variabel Bebas ke-i

$\sum y i^{2}=$ Jumlah kuadrat Variabel Terikat ke- $\mathrm{i}$

Nilai $\mathrm{R}^{2}$ mempunyai nilai 0-1 makin besar $\mathrm{R}^{2}$ (mendekati 1) maka hasil estimasi akan semakin mendekati sebenarnya.

Uji statistik yang digunakan untuk menguji besarnya pengaruh dari seluruh variabel independen secara bersama-sama atau simultan terhadap variabel dependen digunakan uji $F$, untuk menentukan $F_{\text {tabel }}$ tingkat signifikasi yang digunakan sebesar 5\% dengan rumus sebagai berikut (Hasan Iqbal, 2004) :

$$
\mathrm{F}_{\text {hitung }}=\frac{R^{2 / K}}{\left(1-R^{2}\right)(n-k-1)}
$$

Dimana :

$\mathrm{n}$ = Jumlah sampel

$\mathrm{k}=$ Jumlah variabel bebas

$\mathrm{R}^{2}=$ Koefisiensi determinasi

Pengujian ini berdasarkan pada hipotesis statistic dan hipotesis operasional sebagai berikut:

$H_{0} \quad: b_{1}, \mathrm{~b} 2, \mathrm{~b} 3, \mathrm{~b} 4, \mathrm{~b} 5, \mathrm{~b} 6, \mathrm{~b} 7=0$

$H_{1}: b_{1} \mathrm{~b} 2, \mathrm{~b} 3, \mathrm{~b} 4, \mathrm{~b} 5, \mathrm{~b} 6, \mathrm{~b} 7 \neq 0$

Dimana:

Ho : Tidak terdapat pengaruh faktor sosial ekonomi secara simultan terhadap pendidikan formal anak petani ikan

Hi : Terdapat pengaruh faktor sosial ekonomi secara simultan terhadap pendidikan formal anak petani ikan

Untuk mengambil keputusan, maka nilai $\mathrm{F}$ hitung akan di bandingkan dengan $\mathrm{F}$ tabel dengan kaidah keputusan atau kriteria pengujiannya sebagai berikut

F hitung > F tabel : (k) (n-k-1), Ho ditolak

F hitung $\leq \mathrm{F}$ tabel : $(\mathrm{k})(n-k-1)$, Ho diterima

Selang kepercayaan yaitu pada 95\% dan sebagai alat untuk menganalisis data, dipergunakan Statistical Product and Service Solutions (SPSS) for Windows versi 26, untuk mendapatkan hasil yang akurat.

Kemudian pengujian terhadap masing-masing parameter ditunjukkan untuk mengetahui apakah masing-masing variable bebas (independent variabel $=\mathrm{Xi}$ ) secara individu berpengaruh terhadap variabel tidak bebas (dependent variabel $=\mathrm{Y}$ ). Pengujian ini dilakukan dengan menggunakan uji $t_{\text {hitung }}$ dengan rumus (Hasan Iqbal,2006): 
$t_{\text {hitung }}=\frac{b_{i}}{S e_{(b i)}}$

Dimana:

$t_{\text {hitung }}=$ Nilai dari t hitung

$b_{i} \quad=$ koefisien regresi variabel bebas $\mathrm{ke}-\mathrm{i}$

$S_{e} \quad=$ Standar deviasi koefisien regresike $-\mathrm{i}$

Pengujian ini berdasarkan hipotesis statistik dan hipotesis operasional sebagai berikut:

1. Umur : $H_{0}: b_{1}=0$

$$
H_{1}: b_{1}<0
$$

2. Pendidikan Kepala Keluarga $: H_{0}: b_{2}=0$

$$
H_{1}: b_{2} \neq 0
$$

3. Jumlah tanggungan kepala keluarga : $H_{0}: b_{3}=0$

$$
H_{1}: b_{3}<0
$$

4. Penghasilan $: H_{0}: b_{4}=0$

$$
H_{1}: b_{4} \neq 0
$$

5. Jarak Sarana Pendidikan: $H_{0}: b_{5}=0$

6. Jenis Kelamin Anak: $H_{0}: b_{6}=0$

$$
H_{1}: b_{1}<0
$$

$$
H_{1}: b_{6} \neq 0
$$

7. Status Kepemilikan Lahan $: H_{0}: b_{6}=0$

$$
H_{1}: b_{6} \neq 0
$$

$H_{0}=$ Tidak terdapat pengaruh faktor sosial ekonomi secara persial terhadap pendidikan formal anak petani ikan

$H_{1}=$ Terdapat pengaruh faktor sosial ekonomi secara persial terhadap pendidikan formal anak petani ikan.

Kriteria pengujian :

Ho tolak : jika $\mid \mathrm{t}$ hitung $\mid>\mathrm{t} \alpha / 2(\mathrm{n}-\mathrm{k}-1)$

Ho terima : jika $\mid$ t hitung $\mid \leq \mathrm{t} \alpha / 2(\mathrm{n}-\mathrm{k}-1)$

\section{A. Keadaan Umum Lokasi Penelitian}

\section{HASIL PENELITIAN}

Desa Pudak merupakan desa yang terletak di Kecamatan Kumpeh Ulu Kabupaten Muaro Jambi Provinsi Jambi. Desa Pudak terdiri dari 3 Dusun dan 21 RT. Jarak Desa Pudak ke ibu kota kecamatan adalah 0 km, karena ibu kota Kecamatan Kumpeh Ulu adalah di Desa Pudak. Secara administratif batas wilayah Desa Pudak sebelah utara berbatasan dengan Kecamatan Tanggo Rajo, sebelah timur berbatasan dengan Kasang Pudak, Sebelah selatan berbatasan dengan Kota Karang dan Kasang. Sebelah barat berbatasan dengan Muara Kumpeh. Desa Pudak terletak di antara $1^{0-5^{0}}$ samapai $2^{\circ}-20^{\circ}$ Lintang selatan dan $102^{\circ}-25^{0}$ sampai $104^{0-300}$ Bujur timur dengan topografi daratan. Desa Pudak memiliki ketinggian antara 0-10 $\mathrm{m}$ di atas permukaan laut.

Jumlah penduduk Desa Pudak sebanyak 4.394 jiwa, dengan mata pencarian sebagian besar bertani. Sarana prasarana yang dimiliki desa tersebut adalah sarana pendidikan, kesehatan, komunikasi, olah raga, ibadah, pasar dan transportasi. Transportasi menuju Desa Pudak dapat ditempuh dengan menggunakan jalan darat. Dari Kota Jambi, lama perjalanan ke Desa Pudak yaitu 45 menit dengan kendaraan roda 4 atau mobil dan juga kendaraan roda 2 atau motor dengan jalan yang sudah cukup baik/jalan aspal. Secara umum Desa Pudak memiliki aksebilitas yang relatif lebih baik jika dibandingkan dengan Desa lain di Kecamatan Kumpeh Ulu. Potensi daerah tersebut berupa darat yang dimanfaatkan untuk usaha kolam yang menjadi salah satu daerah sentra budidaya ikan kolam. Dalam hal budidaya ikan, teknologi yang dipergunakan masih tradisional. Komoditi yang menjadi andalan adalah ikan patin (Desa Pudak dalam Angka.2020). 
Asmaida dan Arosidin. Pendidikan Formal Anak Pada Keluarga Petani Ikan Di Desa Pudak Kecamatan Kumpeh Ulu Kabupaten Muaro Jambi Provinsi Jambi

\section{B. Karakteristik Responden \\ 1. Umur Responden}

Umur dapat mempengaruhi kemampuan seserang untuk berkerja dan berfikir dalam pengambilan keputusan yang berkaitan dengan kegiatan yang akan di laksanakan umur Responden berkisar antara 29-64 tahun dengan ratarata 41,48 tahun. Untuk lebih jelasnya umur responden petani ikan di Desa Pudak dilihat pada Tabel 1 berikut:

Tabel 1. Distribusi Frekuensi Responden Berdasarkan Kelompok Umur

\begin{tabular}{cccc}
\hline No & Kelompok Distribusi Umur (Tahun) & Frekuensi (KK) & Persentase (\%) \\
\hline 1 & $29-34$ & 8 & 25,81 \\
2 & $35-40$ & 8 & 25,81 \\
3 & $41-46$ & 6 & 19,35 \\
4 & $47-52$ & 4 & 12,9 \\
5 & $53-58$ & 4 & 12,9 \\
6 & $59-64$ & 1 & 3,23 \\
\hline
\end{tabular}

Sumber: Hasil Olahan Data Primer, 2021

Berdasarkan data Tabel 1 diatas dapat dilihat umur petani ikan yang terbanyak berada pada kelompok 29-34 dan 35-40 dengan frekuensi masing-masing $8 \mathrm{KK}$ dengan presentase $25,81 \%$, sedangkan kelompok umur petani yang sedikit berada pada kelompok umur 59-64 dengan frekuensi $1 \mathrm{KK}$ dengan presentase 3,23\%. Jika umur petani sampel tesebut dihubungkan dengan golongan umur penduduk produktif antara 15-54 tahun (Salamun, 1993).

\section{Pendidikan Responden}

Pendidikan adalah hal yang penting sebagai dasar dalam memperoleh pengetahuan dan keterampilan. Pendidikan kepala keluarga pada umumnya berpengaruh pada cara berfikirnya dalam mengambil keputusan untuk memberikan kesempatan pendidikan formal kepada anaknya, pendidikan responden berkisar antara SD-S1 dengan mayoritas pendidikan SMA. Untuk lebih jelasnya dilihat pada Tabel 2 berikut

Tabel 2. Distribusi Frekuensi Responden Berdasarkan Tingkat Pendidikan

\begin{tabular}{cccc}
\hline No. & Tingkat Distribusi Pendidikan & Frekuensi (KK) & Persentase (\%) \\
\hline 1 & SD & 3 & 9,68 \\
2 & SMP & 8 & 25,81 \\
3 & SMA & 15 & 48,39 \\
4 & S1 & 5 & 16,12 \\
\hline
\end{tabular}

Sumber: Hasil Olahan Data Primer, 2021

Dari Tabel 2 di atas dapat dilihat tingkat pendidikan petani ikan yang terbanyak pada jenjang pendidikan SMA yaitu sebnyak $15 \mathrm{KK}$ dengan persentase $48,39 \%$, dan jumlah yang paling sedikit berada pada jenjang Pendidikan SD yaitu $3 \mathrm{KK}$ dengan presentase $9,68 \%$. Rendahnya tingkat pendidikan petani akan berpengaruh terhadap perencanaan dalam pengolahan usahanya hal ini berpengaruh terhadap tingkat produksi yang dihasilkan petani tersebut. Soeharjo dan Patong (1997), menyatakan bahwa semakin tinggi tingkat pendidikan petani maka kemampuan petani untuk meningkatkan pengelolaan usaha taninya akan lebih baik dari segi adaptasi penggunaan teknologi baru.

\section{Jumlah Tanggungan Kepala Keluarga}

Jumlah tanggungan kepala keluarga merupakan salah satu faktor yang mempengaruhi keberhasilan usaha, semakin banyak jumlah tanggungan kepala keluarga maka semakin banyak kebutuhan yang akan dipenuhi oleh petani ikan. Tanggungan kepala keluarga terdiri dari istri, anak serta anggota keluarga lainnya yang tinggal bersama dalam keluarga sekaligus menjadi tanggung jawab kepala kepala keluarga jumlah tanggungan kepala keluarga responden berkisar antara 2 sampai 7 orang dengan rata-rata 3 orang. Untuk lebih jelasnya jumlah tanggungan kepala keluarga petani ikan di lihat pada Tabel 3. 
Asmaida dan Arosidin. Pendidikan Formal Anak Pada Keluarga Petani Ikan Di Desa Pudak Kecamatan Kumpeh Ulu Kabupaten Muaro Jambi Provinsi Jambi

Tabel 3. Distribusi Frekuensi Responden Berdasarkam Jumlah Tanggungan

\begin{tabular}{cccc}
\hline No. & Jumlah Disrtribusi Tanggungan Keluarga(Orang) & Frekuensi (KK) & Persentase (\%) \\
\hline 1 & 2 & 13 & 41,95 \\
2 & 3 & 8 & 25,81 \\
3 & 4 & 5 & 16,12 \\
4 & 5 & 4 & 12,90 \\
5 & 6 & 1 & 3,23 \\
6 & 7 & 0 & 0 \\
\hline
\end{tabular}

Sumber: Hasil Olahan Data Primer, 2021

Berdasarkan Tabel 3 di atas dapat dilihat bahwa petani ikan memiliki frekuensi tanggungan keluarga terbanyak berada pada kelas pertama dengan jumlah tanggungan 2 orang yaitu $13 \mathrm{KK}$ atau sebesar $41,95 \%$ dan petani ikan yang memiliki frekuensi tanggungan keluarga yang sedikit berada pada kelas 5 dengan jumlah tanggungan 6 orang yaitu sebesar $1 \mathrm{KK}$ dengan presentase 3,23\%. Besar kecilnya jumlah tanggungan kepala keluarga seorang petani ikan merupakan salah satu faktor yang menentukan aktivitas dalam usahanya. Menurut Hermanto (1998). Jumlah tanggungan keluarga petani berpengaruh terhadap kegiatan ekonomi.

\section{Penghasilan Kepala Keluarga}

Penghasilan kepala keluarga merupakan salah satu faktor yang mempengaruhi tingkat pendidikan anak untuk melanjutkan pendidikan formal anak, semakin besar pengasilan maka diduga semakin tinggi keinginan kepala keluarga untuk memberikan pendidikan formal kepada anaknya, dapat dilihat penghasilan kepala keluarga di daerah penelitian berkisar antara Rp.2.000.000-6.505.000 dengan rata-rata Rp.4.422.580,65 per bulan, untuk lebih jelasnya dapat dilihat pada Tabel 4.

Tabel 4. Distribusi Frekuensi Responden Berdasarkan Jumlah Penghasilan

\begin{tabular}{cccc}
\hline No & Penghasilan (Rp/bulan) & Frekuensi (KK) & Presentase $(\%)$ \\
\hline 1 & $2,000.000-2.750 .000$ & 4 & 12,90 \\
2 & $2.751 .000-3.501 .000$ & 4 & 12,90 \\
3 & $3.502 .000-4.252 .000$ & 7 & 22,60 \\
4 & $4.253 .000-5.003 .000$ & 6 & 19,35 \\
5 & $5.004 .000-5.754 .000$ & 4 & 12,90 \\
6 & $5.755 .000-6.505 .000$ & 6 & 19,35 \\
\hline
\end{tabular}

Sumber: Hasil Olahan Data Primer, 2021

Dari Tabel 4 di atas dapat dilihat penghasilan petani ikan terbanyak adalah pada kelompok penhasilan Rp 3.600.000-4.252.000 per bulan yaitu sebanyak $7 \mathrm{KK}$ dengan presentase sebesar 22,60\% dan penghasilan petani ikan paling sedikit adalah pada kelompok penghasilan Rp.2.000.000-2.750.000, Rp.2.751.000-3.501.000, dan 5.004.0005.754 .000 per bulan yaitu masing-masing sebanyak 4 KK dengan presentase sebesar $12.90 \%$.

\section{Jarak Sarana Pendidikan}

Jarak sarana pendidikan adalah jarak tempuh dari rumah ke lokasi sarana pendidikan, jarak lokasi sarana pendidikan berpengaruh terhadap pendidikan formal yang akan diberikan oleh petani kepada anaknya Jarak tempuh lokasi rumah petani ke lokasi sarana Pendidikan berkisar antara 0,5-27,4 Km dengan rata-rata jarak tempuh 8,02 Km dilihat pada Tabel 5 berikut.

Tabel 5. Distribusi Frekuensi Responden Berdasarkan Jarak Tempuh Ke Lokasi Sarana Pendidikan

\begin{tabular}{cccc}
\hline No & Jarak Distribusi $(\mathbf{K m})$ & Frekuensi $(\mathbf{K K})$ & Presentase $(\%)$ \\
\hline 1 & $0,5-4,9$ & 11 & 35,48 \\
2 & $5,0-9,4$ & 8 & 25,80 \\
3 & $9,5-13,9$ & 8 & 25,80 \\
4 & $14,0-18,4$ & 2 & 6,46 \\
5 & $18,5-22,9$ & 0 & 0 \\
6 & $23,0-27,4$ & 2 & 6,46 \\
\hline
\end{tabular}

Sumber: Hasil Olahan Data Primer, 2021 
Asmaida dan Arosidin. Pendidikan Formal Anak Pada Keluarga Petani Ikan Di Desa Pudak Kecamatan Kumpeh Ulu Kabupaten Muaro Jambi Provinsi Jambi

Berdasarkan Tabel 5 di atas bahwa frekuensi jarak tempuh paling banyak berada pada jarak 0,5-4,9 $\mathrm{Km}$ sebanyak $11 \mathrm{KK}$ atau sebesar 35,48\% dan frekuensi yang sedikit berada pada jarak 14,0-18,4 Km dan 23,0 -27,4 yaitu masing-masing sebnyak 2 KK dengan frekuensi 6,46\%.

\section{Jenis Kelamin Anak}

Menurut Hungu (2016), jenis kelamin merupakan perbedaan antara perempuan dengan laki-laki secara biologis sejak seseorang itu dilahirkan. Jenis kelamin anak petani ikan dalam keluarga yang mengikuti pendidikan formal tertinggi dalam keluarga yang terdiri dari jenis kelamin laki-laki dan perempuan. Untuk lebih jelasnya dapat dilihat pada Tabel 6 berikut:

Tabel 6. Distribusi Frekuensi Responden Berdasarkan Jenis Kelamin Anak Yang Berpendidikan Paling Tinggi Dalam Keluarga

\begin{tabular}{cccc}
\hline No & Jeniis Kelamin Anak & Frekuensi $(\mathbf{K K})$ & Presentase $(\boldsymbol{\%})$ \\
\hline 1 & Laki-laki & 19 & 61,29 \\
2 & Perempuan & 12 & 38,71 \\
\hline & Jumlah & 31 & 100 \\
\hline
\end{tabular}

Sumber: Hasil Olahan Data Primer, 2021

Berdasarkan Tabel 6 di atas bahwa frekuensi jenis kelamin anak lebih banyak berada pada kelompok jenis kelamin laki-laki $19 \mathrm{KK}$ dengan presenase $61,29 \%$, dan jenis kelamin yang lebih rendah berada pada kelompok jenis kelamin perempuan yaitu sebanyak $12 \mathrm{KK}$ dengan presentase $38,71 \%$. Berdasarkan wawancara dengan petani, bahwa anak laki-laki mempunyai kesempatan yang lebih besar di banding anak peremdengan alasan anak laki-laki adalah harapan keluarga untuk dapat bekerja mencari nafkah untuk menhidupi keluarganya dan bertanggung jawab kepada orang tuanya.

\section{Status Kepemilikan Lahan}

Status kepemilikan lahan adalah status dari lahan yang di usahakan petani ikan sebagai kegiatan sumber mata pencaharian untuk membiayai kehidupan keluarga, status kepemilikan lahan berdasarkan lahan petani sendiri dan petani penggarap, untuk lebih jelasnya dapat di lihat pada Tabel 7.

Tabel 7. Distribusi Frekuensi Status Kepemilikan Lahan

\begin{tabular}{|c|c|c|c|}
\hline No & Kepemilikan Lahan & $\begin{array}{l}\text { Frekuensi } \\
\text { (KK) }\end{array}$ & $\begin{array}{c}\text { Persentase } \\
(\%)\end{array}$ \\
\hline 1 & Milik Sendiri & 30 & 100 \\
\hline 2 & Petani Penggarap & 0 & 0 \\
\hline & Jumlah & 30 & 100 \\
\hline
\end{tabular}

Sumber: Hasil Olahan Data Primer, 2021

Berdasarkan Tabel 7 di atas dapat dilihat bahwa lahan usaha ikan adalah 100\% berstatus milik petani sendiri, dan tidak terdapat sebagai petani penggarap. Variabel bebas ini tidak diikut sertakan dalam model karena variasi data yang sama.

\section{Sebaran Tingkat Pendidikan Formal Anak}

Pendidikan anak sebagai posisi sentral sangat di pengaruhi oleh tiga unsur yaitu keluarga, masyarakat dan sekolah. Dalam penelitian ini yang dikaji sebagai faktor penentu atau yang mempengaruhi tinggi rendahnya tingkat pendidikan formal anak dalam lingkup keluarga adalah melalui faktor sosial ekonomi keluarga. Faktor sosial ekonomi yang diduga mempengaruhi tingkat pendidikan formal anak pada keluarga petani ikan antara lain adalah umur kepala keluarga, tingkat pendidikan kepala keluarga, jumlah tanggungan kepala keluarga, penghasilan kepala keluarga, jarak sarana pendidikan, jenis kelamin anak, status kepemilikan lahan. Distribusi tingkat pendidikan formal anak pada keluarga petani ikan dapat dilihat pada Tabel 8 .

Tabel 8. Kategori dan Distribusi Tingkat Pendidikan Formal Anak pada Keluarga Petani Ikan

\begin{tabular}{ccccc}
\hline No & Distribusi Tingkat Pendidikan Formal Anak Petani Ikan & Kategori & Frekuensi $($ KK) & Presentase (\%) \\
\hline 1 & SD & Rendah & 8 & 25,81 \\
2 & SMP & Rendah & 7 & 22,59 \\
3 & SMA & Sedang & 12 & 38,71 \\
4 & D3 & Tinggi & 1 & 3,22 \\
5 & S1 & Tinggi & 3 & 9,67 \\
\hline & Jumlah & & 31 & 100 \\
\hline
\end{tabular}

Sumber: Hasil Olahan Data Primer, 2021 
Berdasarkan Tabel 8 di atas dapat dilihat bahwa sebaran tingkat pendidikan formal anak petani ikan terbanyak berada pada tingkat pendidikan kategori rendah (SD dan SMP) yaitu dengan frekuensi $15 \mathrm{KK}$ dengan presentase 48,40\% dan sebaran tingkat pendidikan yang paling sedikit yaitu pada tingkat pendidikan kategori tinggi (D3 dan S1) dengan frekuensi 4 KK dan frekuensi 12,89\%. Dari hasil penelitian ini terlihat bahwa pendidikan formal anak petani ikan di Desa Pudak Kecamatan Kumpeh Ulu dapat dikatakan masih tergolong rendah.

Rendahnya tingkat pendidikan anak di kalangan responden di Desa Pudak Kecamatan Kumpeh Ulu disebabkan oleh berbagai faktor antara lain adanya faktor orang tua yang lebih mengarahkan anaknya untuk melanjutkan usahanya yang sudah menjadi turun temurun, sehingga tidak terpikirkan untuk sekolah dan juga disebabkan oleh keterbatasan biaya sehingga tidak melanjutkan ke jenjang pendidikan yang lebih tinggi. Hal ini sejalan dengan hasil penelitian Suryani Nani at all , 2004, Rendahnya tingkat pendidikan di kalangan petani (nelayan) disebabkan oleh berbagai faktor antara lain adanya faktor orang tua yang lebih mengarahkan anaknya untuk menjadi nelayan dan dikenalkan pada laut sejak kecil sehingga tidak terpikirkan untuk sekolah dan juga adanya keterbatasan biaya dan ada pula yang keinginan dirinya untuk menjadi nelayan sehingga tidak melanjutkan ke jenjang pendidikan yang lebih tinggi.

\section{Persepsi Keluarga Petani Ikan Terhadap Pendidikan Formal Anak}

Sarwono (1999) dalam Suryani Nani at all (2004) yang mendefinisikan persepsi sebagai proses pencarian informasi untuk dipahami melalui alat penginderaan (penglihatan. pendengaran. peraba dan sebagainya) dan alat untuk memahaminya adalah kognisi atau kesadaran. Dalam hal pemenuhan kebutuhan pendidikan formal anak. orang tua harus memiliki persepsi yang baik sebelum melakukan tindakan untuk menyekolahkan anak ke jenjang pendidikan formal. Hal itu sesuai dengan ungkapan Sadli (1977) bahwa perilaku seseorang tidak teriepas dari cara mempersepsikan situasi.

Berdasarkan hasil penelitian, secara umum persepsi keluarga petani ikan di Desa Pudak Kecamatan Kumpeh Ulu yang diwakili oleh kepala keluarga mempersepsikan bahwa pendidikan formal merupakan suatu hal yang penting untuk anak-anaknya. Bagi petani menyekolahkan anak adalah untuk bekal hidup anak di masa yang akan datang dengan harapan dapat memperoleh pengetahuan yang banya, memperoleh pekerjaan yang layak dan memperoleh penghidupan yang lebih baik dari kondisi orang tuanya. Kenyataan yang terjadi pada keluarga petani ikan di Desa Pudak Kecamatan Kumpeh Ulu adalah adanya ketidakkonsistenan antara persepsi dengan perilaku untuk menyekolahkan anak karena adanya berbagai faktor yang mempengaruhi pendidikan anak antara lain adalah penghasilan keluarga dan jarak lokasi sarana Pendidikan.

Persepsi yang dimiliki oleh seseorang dapat berbeda dengan persepsi orang lain. Perbedaan persepsi yang dimiliki oleh seseorang dalam hal ini petani ikan dapat dipengaruhi oleh faktor internal individu dan faktor eksternal. Faktor utama yang mempengaruhi persepsi petani ikan di Desa Pudak Kecamatan Kumpeh Ulu berasal dari faktor individu kepala keluarga yaitu harapan orang tua terhadap anak dan pengalaman masa lalu orang tua. Suryani Nani at all (2004), menyatakan secara umum persepsi keluarga nelayan yang diwakili oleh kepala keluarga memepersepsikan bahwa pendidikan formal merupakan suatu hal yang penting untuk anak-anaknya. Bagi para nelayan menyekolahkan anak adalah untuk bekal hidup anak di masa yang akan datang dengan harapan dapat memperoleh pekerjaan yang layak dan memperoleh penghidupan yang lebih baik dari kondisi orang tuanya.

\section{E. Analisis Faktor-faktor yang Mempengaruhi Tingkat Pendidikan Formal Anak Pada Keluarga Petania Ikan}

Dalam penelitian ini dihipotesiskan bahwa faktor : umur kepala keluarga, tingkat pendidikan kepala keluarga, jumlah tanggungan kepala keluarga, penghasilan kepala keluarga, jarak sarana pendidikan, jenis kelamin anak, status kepemilikan lahan berpengaruh terhadap tingkat pendidikan formal anak pada keluarga petani ikan di Desa Pudak Kecamatan Kumpeh Ulu. Untuk melihat pengaruh faktor-faktor tersebut terhadap pendidikan formal anak petani ikan di lakukan analisis regresi linier berganda.

Berdasarkan hasil penelitian bahwa variabel status kepemilikan lahan (D2) adalah $100 \%$ milik sendiri maka variabel status kepemilikan lahan tersebut di keluarkan dari model karena memiliki variasi data yang sama, sehingga variabel bebas menjadi 6 variabel. Hasil analisis uji regresi linier berganda dengan bantuan computer (program SPSS) dapat dilihat pada Tabel 9.

Tabel 9. Hasil Analisis Regresi Linier Berganda

\begin{tabular}{llllll}
\hline Variabel & $\begin{array}{l}\text { Koefisien } \\
\text { regresi }\end{array}$ & $\begin{array}{l}\text { Standar } \\
\text { error }\end{array}$ & $\mathbf{t}_{\text {hitung }}$ & t tabel & Sig \\
\hline Konstanta & 4,028 & 2,523 & 1,596 & 2,064 &, 123 \\
Umur Kepala Keluarga (X1) &, 028 &, 025 & 1,119 & 2,064 &, 274 \\
Tingkat Pendidikan Kepala Keluarga (X2) &,- 114 &, 113 & $-1,006$ & 2,064 &, 324 \\
Jumlah Tanggungan Kepala Keluarga (X3) &, 058 &, 185 &, 314 & 2,064 &, 756 \\
Penghasilan Kepala Keluarga (X4) & $9,848 E-007$ &, 000 & 3,347 & 2,064 &, $003 *$ \\
\hline
\end{tabular}


Asmaida dan Arosidin. Pendidikan Formal Anak Pada Keluarga Petani Ikan Di Desa Pudak Kecamatan Kumpeh Ulu

\begin{tabular}{llllll}
\hline Jarak Sarana Pendidikan (X5) &, 241 &, 055 & 4,382 & 2,064 &, $000^{*}$ \\
Jenis Kelamin (D1) &, 091 &, 479 &, 190 & 2,064 &, 851 \\
\hline Adjusted R square $=0,855$ & & & & & \\
Nilai F hitung $\quad=30,501$ & & & & & \\
Nilai F tabel $\quad=2,51$ & & & & & \\
$\alpha$ & $=5 \%$ atau 0,05 & & & & \\
$*$ *berpengaruh nyata pada $\alpha=5 \%$ & & & & \\
\hline
\end{tabular}

Sumber: Hasil Olahan Data Primer, 2021

"Berdasarkan hasil analisis regresi pada Tabel 9 di atas, diperoleh persamaan regresi sebagai berikut :" $\mathrm{Y}=4,028+0,028 \mathrm{X}_{1}-0,114 \mathrm{X}_{2}+0,058 \mathrm{X}_{3}+0,0009848 \mathrm{X}_{4}+0,241 \mathrm{X}_{\mathrm{s}}+0,091 \mathrm{D} 1_{\mathrm{i}}+\mathrm{e}$

\section{a). Analisis Uji Keragaman (Uji F)}

Menurut Iman Ghozali (2001), uji statistik yang digunakan untuk menguji besamya pengaruh dari seluruh variabel independen secara bersama-sama atau simultan terhadap variabel dependen digunakan Uji-F. Dalam penelitian ini analisis uji $\mathrm{F}$ digunakan untuk menyatakan bahwa variabel independen yang terdiri atas penghasilan keluarga, umur kepala keluarga, tingkat pendidikan kepala keluarga, jumlah tanggungan kepala keluarga, jenis kelamin dan jarak sarana pendidikan berpengaruh terhadap variable dependen yaitu pendidikan formal anak pada keluarga petani ikan. Jika $F_{\text {hitung }} \geq \mathrm{F}_{\text {tabel }}$ maka variabel-variabel independen tersebut mempunyai pengaruh yang signifikan terhadap pendidikan formal anak pada keluarga petani ikan. Sedangkan jika $F_{\text {hitung }}<F_{\text {tabel }}$ maka variabelvariabel independen mempunyai pengaruh yang tidak signifikan terhadap pendidikan formal anak pada keluarga petani ikan. Tabel tingkat signifikan yang digunakan adalah sebesar 5\%.

Berdasarkan data analisis SPSS diperoleh nilai $\mathrm{F}$ hitung $=30,501$ lebih besar dari $\mathrm{F}$ tabel sebesar 2,51. Hal yang sama bisa juga dilihat dari nilai signifikasi $F(0,00)$ yang lebih kecil dari 0,05 . Nilai ini menunjukkan secara simultan variabel-variabel bebas (penghasilan keluarga, umur kepala keluarga, tingkat pendidikan kepala keluarga, jumlah tanggungan kepala keluarga, jenis kelamin dan jarak sarana pendidikan) memberikan pengaruh secara nyata terhadap variabel dependen (pendidikan formal anak pada keluarga petani) di Desa Pudak Kecamatan Kumpeh Ulu. Dari hipotesis atau hasil uji tersebut ternyata hipotesis penelitian yang menyatakan dugaan variabel independen (umur kepala keluarga, pendidikan kepala keluarga, jumlah tanggungan kepala keluarga, penghasilan kepala keluarga, jarak sarana pendidikan, jenis kelamin anak), secara bersama-sama berpengaruh terhadap pendidikan formal anak pada keluarga petani ikan di Desa Pudak Kecamatan Kumpeh Ulu Kabupaten Muaro Jambi, dapat diterima.

\section{b). Analisis Uji Koefisien Determinasi $\left(\mathbf{R}^{2}\right)$}

Uji koefisien determinasi menunjukkan seberapa baik variabel-variabel bebas menjelaskan hasil (multiple correlation coefficient). Kisaran nilai $\mathrm{R}$ adalah 0 hingga 1 . Semakin nilai $\mathrm{R}$ mendekati angka 1, maka semakin kuat variabel-variabel bebas memprediksikan variabel terikat. Dalam penelitian ini, nilai Adjusted $R^{2}$ Square $=0,855$ atau mencapai $85,5 \%$, angka tersebut menunjukkan bahwa kemampuan variabel bebas dalam memberikan informasi untuk menjelaskan kegaraman variabel terikat relatif tinggi. Sehingga dari hasil tersebut dapat disimpulkan bahwa variabel bebas (umur kepala keluarga, pendidikan kepala keluarga, jumlah tanggungan kepala keluarga, penghasilan kepala keluarga, jarak sarana pendidikan, jenis kelamin anak) memiliki pengaruh yang besar terhadap peningkatan maupun penurunan pendidikan formal anak pada keluarga petani ikan dan sisanya sebesar 14,5\% tidak dapat dijelaskan oleh model, akan tetapi dijelaskan oleh faktor lain. Apabila dilihat secara keseluruhan bahwa model yang digunakan dalam penelitian ini cukup baik. Bearti model yang digunakan untuk analisis ini baik untuk mengestimasi variabel-variabel yang diikutsertakan dalam model berdasarkan data yang ada $\mathrm{R}^{2}$ ini berfungsi untuk mengukur keputusan yang baik dari persamaan analisis regresi dan jika ada observasi tepat pada garis estimasi maka data hasil sampel hamper mendekati keadaan yang sebenarnya.

\section{c). Analisis Koefisien Regresi (Uji t)}

Dalam persamaan regresi suatu penelitian, nilai koefisien pada masing-masing variabel independen (umur kepala keluarga, pendidikan kepala keluarga, jumlah tanggungan kepala keluarga, penghasilan kepala keluarga, jarak sarana pendidikan, jenis kelamin anak) harus melalui pengujian secara satu persatu, hal ini bertujuan untuk mengetahui variabel independen yang mana yang memiliki pengaruh nyata terhadap variabel dependen (pendidikan formal anak pada keluarga petani ikan). Uji signifikansi merupakan salah satu bagian dalam analisis regresi linear, dalam uji signifikansi ini menggunakan data yang terdapat pada Tabel 12 yang menunjukkan nilai koefisien $t$ untuk masing-masing variabel independen. Apabila signifikansi t yang digunakan sebagai ukuran, maka nilai signifikansi $t$ tersebut harus dibandingkan dengan tingkat alpha $(\alpha=0,05)$. Apabila signifikansi $t_{\text {hitung }}<\mathrm{t}_{\text {tabel, }}$ maka dinyatakan signifikan. Namun apabila signifikansi $t_{\text {hitung }}>t_{t a b e l}$, maka dinyatakan tidak signifikan. Apabila hal ini terjadi maka 
tidak ada pengaruh variabel independen terhadap variabel dependen. Adapun pembahasan uji signifikansi akan dijelaskan sebagai berikut :

\section{Umur kepala keluarga (X1)}

Berdasarkan uji parsial yang dilakukan terhadap variabel umur kepala keluarga, ternyata variabel ini tidak berpengaruh signifikan dilihat dari sig $\mathrm{t}=0,274$ yang lebih besar dari $\alpha=0,05$, untuk hipotesis bisa dilihat dari $\mathrm{t}_{\text {hitung }}$ 1,119 yang lebih kecil jika dibandingkan dengan $t_{\text {tabel }}=2,064$, maka Ho diterima dan H1 ditolak. Dengan demikian hipotesis yang menyatakan bahwa umur kepala keluarga berpengaruh terhadap pendidikan formal anak pada keluarga petani ikan di Desa Pudak Kecamatan Kumpeh Ulu, tidak dapat diterima.

\section{Tingkat Pendidikan Kepala Keluarga (X2)}

Berdasarkan uji parsial yang dilakukan terhadap variabel tingkat pendidikan kepala keluarga, ternyata variabel ini tidak berpengaruh signifikan dilihat dari sig $\mathrm{t}=0,324$ yang lebih besar dari $\alpha=0,05$, untuk hipotesis bisa dilihat dari $\mathrm{t}_{\text {hitung }}$ 1,006 yang lebih kecil jika dibandingkan dengan $\mathrm{t}$ tabel $=2.064$, maka Ho diterima dan $\mathrm{H} 1$ ditolak. Dengan demikian hipotesis yang menyatakan bahwa tingkat pendidikan kepala keluarga berpengaruh terhadap pendidikan formal anak pada keluarga petani ikan di Desa Pudak Kecamatan Kumpeh Ulu, tidak dapat diterima.

\section{Jumlah Tanggungan Kepala Keluarga (X3)}

Berdasarkan uji parsial yang dilakukan terhadap variabel jumlah tanggungan kepala keluarga, terny ata variabel ini tidak berpengaruh secara signifikan dilihat dari sig $\mathrm{t}=0,756$ yang lebih besar dari $\alpha=0,05$, untuk hipotesis bisa dilihat dari $t_{\text {hitung }}=0,314$ yang lebih kecil jika dibandingkan dengan tabel $t_{\text {tabel }}=2,064$, maka Ho diterima dan H1 ditolak. Dengan demikian hipotesis yang menyatakan bahwa jumlah tanggungan keluarga berpengaruh terhadap pendidikan formal anak pada keluarga petani ikan di Desa Pudak Kecamatan Kumpeh Ulu, tidak dapat diterima.

\section{Penghasilan Kepala Keluarga (X4)}

Berdasarkan Uji Parsial yang dilakukan terhadap variable pengasilan kepala keluarga, ternyata variabel ini berpengaruh signifikan di lihat dari sig $\mathrm{t}=0,003$ yang lelih kecil dari $\alpha=0,05$, untuk hipotesis bisa dilihat dari $\mathrm{t}_{\text {hitung }}=3,437$ yang lebih besar di bandingkan dengan $t$ tabel $=2,064$, maka Ho ditolak dan $\mathrm{H} 1$ diterima. Dengan demikian hipotesis yang menyatakan bahwa penghasilan petani ikan berpengaruh terhadap pendidikan formal anak pada keluarga petani ikan di Desa Pudak Kecamatan Kumpeh Ulu dapat diterima. Nilai koefisien regresi sebesar 0,0009848 menunjukkan bahwa penambahan jumlah penghasilan sebesar Rp 1,00/bulan akan meningkatkan pendidikan formal anak rata-rata sebesar 0,0009848 tahun, dengan asumsi faktor yang lain dalam keadaan konstan. Semakin tinggi penghasilan kepala keluarga maka pendidikan formal anak petani ikan semakin tinggi, hal tersebut berhubungan dengan biaya yang dikeluarkan oleh keluarga, semakin besar penghasilan yang diterima kepala keluarga maka kemampuan untuk memenuhi alokasi biaya pendidikan formal anaknya ke jenjang yang lebih tinggi semangkin mudah.

\section{Jarak Sarana Pendidikan (X5)}

Berdasarkan uji parsial yang dilakukan terhadap variabel jarak sarana pendidikan, ternyata variabel ini berpengaruh secara signifikan dilihat dari sig $\mathrm{t}=0,000$ yang lebih kecil dari $\alpha=0,05$, untuk hipotesis bisa dilihat dari $\mathrm{t}_{\text {hitung }}=4,382$ yang lebih besar jika dibandingkan dengan tabel $\mathrm{t}_{\text {tabel }}=2,064$, maka Ho ditolak dan H1 diterima. Dengan demikian hipotesis yang menyatakan bahwa jarak sarana pendidikan berpengaruh terhadap pendidikan formal anak dapat diterima. Nilai koefisien regresi sebesar 0,241menunjukkan bahwa bertambah jauhnya jarak sarana pendidikan sebesar $1 \mathrm{~km}$ akan meningkatkan tingkat pendidikan formal anak rata-rata sebesar 0,241 tahun, dengan asumsi faktor yang lain dalam keadaan konstan. Semakin jauh jarak sarana pendidikan maka akan semangkin tinggi pendidikan formal anak pada keluarga petani ikan di Desa Pudak Kecamatan Kumpeh Ulu.

Jarak dengan sarana pendidikan juga dijadikan pertimbangan dalam menyekolahkan anak karena terkait dengan transportasi, biaya dan waktu pengawasan kemajuan prestasi anak (Heryanto 1998), sehingga tak mengherankan bila tingkat pendidikan anak yang berada di daerah petani lebih rendah bila dibandingkan dengan daerah lain yang jaraknya lebih dekat dengan sarana pendidikan. Berbeda halnya dengan kondisi pendidikan di Desa Pudak, yang kondisi pendidikan formal anaknya relatif masih rendah. Hasil analisis yang menunjukan bahwa semakin jauh jarak sarana akan semakin tinggi pendidikan formal anaknya. Hal ini diduga bahwa keluarga petani untuk menyekolahkan anaknya bukan dilihat hanya dari jarak tempuhsaja tetapi mereka menyekolahkan anak juga mempertimbangakan kwalitas sarana dan mutu pendidikan yang sesuai dengan yang diharapkan. 


\section{Jenis Kelamin Anak (D1)}

Berdasarkan uji parsial yang dilakukan terhadap variabel Nilai status kelamin anak (D1), ternyata variabel ini tidak berpengaruh secara signifikan dilihat dari sig $\mathrm{t}=0,851$ yang lebih besar dari $\alpha=0,05$, untuk hipotesis bisa dilihat dari t hitung = 0,190 yang lebih tinggi dari perempuan jika dibandingkan dengan tabel t tabel 2,064 maka Ho diterima dan H1 ditolak. Dengan demikian hipotesis yang menyatakan bahwa jenis kelamin anak berpengaruh terhadap pendidikan formal anak tidak dapat diterima. Hal itu menunjukan bahwa nilai anak tidak berpengaruh nyata terhadap tingkat pendidikan formal anak pada keluarga petani ikan. Nilai anak dihubungkan dengan pendidikan formal anak, karena biasanya anak laki-laki lebih cenderung untuk melanjutkan pendidikan formal dibandingkan dengan anak perempuan.

Suryani Nani, at all, (2004), menyatakan bahwa harapan yang dimiliki orang tua untuk keberhasilan anak, akan menuntut para orang tua untuk memenuhi kebutuhan anak salah satunya dengan memberikan pendidikan formal yang memadai, sedangkan bagi anak, harus berusaha untuk memberi makna lain terhadap kehidupan orang tua salah satunya dengan menyelesaikan pendidikan formal. Namun dalam kenyataannya, tidak semua orang tua dan anak dapat mewujudkan nilai tersebut karena adanya hambatan faktor ekonomi dan keinginan yang berbeda antar anak laki-laki dan perempuan.

\section{KESIMPULAN}

1. Sebaran tingkat pendidikan anak petani ikan di Desa Pudak Kecamatan Kumpeh Ulu Kabupaten Muaro Jambi, memiliki penyebaran tingkat pendidikan yang tidak merata antar tingkat pendidikan rendah (SD dan SMP), pendidikan sedang (SMA), dan pendidikan tinggi (D3 dan S1). Presentase seberan tertinggi yaitu pada kategori rendah (Pendidikan SD dan SLTP) yaitu 48,40\%. Sedangkan persentase pada kategori sedang (pendidkan SLTA) adalah 38,71\% dan kategori Tinggi (pendidikan D3 dan S1) adalah sebesar 12,89\%. “

2. Persepsi keluarga petani ikan terhadap pendidikan formal anak secara umum memiliki penilaian yang positif. Namun, persepsi yang muncul tidak selalu menimbulkan perilaku untuk menyekolahkan anaknya ke jenjang yang lebih tinggi.

3. Berdasarkan hasil pengujian statistik dengan menggunakan regresi linear berganda, secara simultan (umur kepala keluarga, pendidikan kepala keluarga, jumlah tanggungan kepala keluarga, penghasilan kepala keluarga, jarak sarana pendidikan, jenis kelamin anak) memberikan pengaruh secara nyata terhadap pendidikan formal anak pada keluarga petani ikan di Desa Pudak Kecamatan Kumpeh Ulu. Uji secara parsial ada dua faktor yang signifikan mempengaruhi tingkat pendidikan formal anak pada keluarga petani ikan yaitu penghasilan keluarga dan jarak tempat tinggal dengan sarana pendidikan. Koefisien determinasi untuk kedua faktor tersebut sebesar $85,5 \%$ yang berarti bahwa kedua faktor tersebut sebagai variabel bebas mampu menjelaskan tingkat pendidikan formal anak sebagai variabel tidak bebas dan sekitar 14,5\% tidak dapat dijelaskan oleh model tetapi dijelaskan oleh faktor lain di luar model tersebut.

\section{DAFTAR PUSTAKA}

Abdul Kadir. 2012. Dasar-Dasar Pendidikan. Jakarta: Kencana.

Abdul Latif. 2009. Pendidikan Berbasis Nilai Masyarakat. Bandung: PT Refika Aditama.

As"earil Muhajir. 2016. Ilmu Pendidikan Perspektif Kontekstual. Jogjakarta: Ar- Ruzz Media.

Aslikudin. Nur. 2016. Persepsi Masyarakat Tentang Pentingnya Pendidikan Formal Imflikasinya Dalam Sikap Kedewasaan Anak di Dusun Samoyo, Desa Sugihmas, Kecamatan Grabag, Kabupaten Magelang Tahun 2015.

Asmaida dan Rogayah. 2020. Peran dan Kontribusi Curahan Waktu Kerja Wanita Pada Usaha Pembesaran Ikan Patin (Pangasius sp) Dalam Kolam (Studi Kasus Di Desa Pudak Kecamatan Kumpeh Ulu Kabupaten Muaro Jambi). Jurnal Media Agribisnis Vol 5 No. 2 Oktober 2020, pp. 74-82. ISSN 2548-7027 (Print), ISSN 25416898 (Online), DOI 10.33087/mea.v5i2.78. http://mea.unbari.ac.id/index.php/MEA/index

Astiti T. 1999. Nilai Anak dalam Kehidupan Keluarga Orang Bali. Didalam: Ihromi TO, editor. Bunga Rampai Sosiologi Keluarga. Jakarta : Yayasan Obor Indonesia.

Dahuri, Rokhmin, Dkk. 2004. Pengelolaan Sumberdaya Wilayah Pesisir dan Laut Secara Terpadu. edisi revisi ke-3 Penerbit PT. Paradnya Paramita, Jakarta.

Departemen Pendidikan dan Kebudayaan. 1995. Fungsi Keluarga dalam Peningkatan Kualitas Sumberdaya Manusia. Jakarta Eddy Soeryatno Soegoto. 2008. Menciptakan Strategi Keunggulan Bersaing Perguruan Tinggi. Yogyakarta: Graha Ilmu.

Ghozali, Imam.2001. Aplikasi Analisis Multivariate Dengan Program SPSS. Badan Penelitian Univeritas Diponegoro. Semarang.

Hasbullah. 2012. Dasar-Dasar Ilmu Pendidikan. Jakarta: Rajawali Press

Harmayani. 2017. Persepsi Keluarga Petani Terhadap Pendidikan Formal Anak. 
Asmaida dan Arosidin. Pendidikan Formal Anak Pada Keluarga Petani Ikan Di Desa Pudak Kecamatan Kumpeh Ulu Kabupaten Muaro Jambi Provinsi Jambi

Heryanto N. 1998. Partisipasi Orang Tua dalam Program Wajib Belajar Pendidikan Dasar 9 Tahun. [Tesis]. Bogor: Institut Pertanian Bogor, Fakultas Pascasarjana.

Hungu. 2007. Pengetian Jenis Kelamin Anak. PT. Gramedia

Indriyanti, Ninuk, Dkk. 2013. Faktor-Faktor yang Memengaruhi Minat Melanjutkan Pendidikan ke Perguruan Tinggi pada Siswa Kelas XII Akuntansi SMK Negeri 6 Surakarta tahun 2013. Jurnal Pendidikan, (Online). UNS, Vol. 1, No. 2, di akses 20 April 2019.Jakarta: Kalam Mulia.

Musaheri. 2007. Pengantar Pendidikan. Jogjakarta: Ircisod. Nasution, S. 2009. Sosiologi Pendidikan. Jakarta: PT Bumi Aksara.

Silalahi, Ulber. 2010. Metode Penelitian Sosial. Refika Aditama. Jakata.

Singarimbun, Masri. 1994. Metode Penekitian, LPS3ES. Jakarta.

Sodikin dan Riyono. 2014. Akutansi Pengantar 1. Sekolah Tinggi Ilmu Manajemen YKPN. Yogyakarta.

Sudiyono. 2004. Manajemen Pendidikan Tinggi. Jakarta: PT Rineka Cipta. Sugeng Sejati. 2012. Psikologi Sosial. Yogyakarta: Teras.

Sugiyono. 2012. Metode Penelitian pendidikan Pendekatan Kuantitatif/kualitatif, dan R\&D. Bandung: Alfabeta.

Suprijanto, A. 2009. Pendidikan oleh Orang Dewasa; dari Teori Hingga Aplikasi. Bumi Aksara. Jakata.

Suryani Nani, At All. 2004. Analisis Penoioikan Formal Anak Paoa Keluarga Nelayan Di Desa Karangjalaori, Kecamatan Parigi, Kasupaten Ciamis, Provinsi Jawa Sarat. Buletin Ekonomi Perikanan Vol. V. No.2 Tahun 2004.

Winarno. S. 1994. Pengantar Peneltian Ilmiah (Dalam Metode Tehnik). Kansius.Bandung. 